Volume 9

Number 3 Volume 9, No. 3, Special Issue

Article 7

Fall 2016: Emerging Threats

\title{
No Place to Hide: Edward Snowden, the NSA, and the U.S. \\ Surveillance State. By Glenn Greenwald, New York, NY: \\ Metropolitan Books, 2014.
}

Richard J. Kilroy Jr., Ph.D.

Assistant Professor of Politics, Coastal Carolina University

Follow this and additional works at: https://digitalcommons.usf.edu/jss

pp. 99-102

\section{Recommended Citation}

Kilroy, Richard J. Jr., Ph.D.. "No Place to Hide: Edward Snowden, the NSA, and the U.S. Surveillance State. By Glenn Greenwald, New York, NY: Metropolitan Books, 2014.." Journal of Strategic Security 9, no. 3 (2016) : 99-102.

DOI: http://dx.doi.org/10.5038/1944-0472.9.3.1552

Available at: https://digitalcommons.usf.edu/jss/vol9/iss3/7

This Book Review is brought to you for free and open access by the Open Access Journals at Digital Commons @ University of South Florida. It has been accepted for inclusion in Journal of Strategic Security by an authorized editor of Digital Commons @ University of South Florida. For more information, please contact digitalcommons@usf.edu. 
No Place to Hide: Edward Snowden, the NSA, and the U.S. Surveillance State. By Glenn Greenwald, New York, NY:

Metropolitan Books, 2014. 
No Place to Hide: Edward Snowden, the NSA, and the U.S. Surveillance State. By Glenn Greenwald, New York, NY: Metropolitan Books, 2014. ISBN 978-1-62779-073-4. Classified Diagrams and Slides in Text. Acknowledgements. Pp.1-26o. \$16.00.

Glenn Greenwald is no stranger to controversy and his book documenting his relationship with Edward Snowden adds to his reputation for challenging conventions and institutions. Journalist, activist, lawyer, and "Global Thinker," are just a few of the titles Greenwald holds, although the one he would most like to be remembered for in publishing this text is probably "fearless" for taking on such a sensitive topic.

Greenwald first took an interest in national security and intelligence issues in 2005, when he became aware of the George W. Bush Administration's authorizing the U.S. intelligence community to exercise broad authorities in pursuit of its Global War on Terror. By extending intelligence collection beyond just foreign targets to U.S. citizens, Greenwald was angered by the extent that what he calls, "the U.S. Surveillance State," has penetrated the lives of all Americans. Such actions are not completely new, as reflected in the title of his text ("no place to hide"), taken from a comment by former Senator Frank Church, who in the 1970 s headed a committee to explore alleged abuses by the intelligence community in targeting U.S. citizens during the Vietnam War. The impact of technology then caused concern by Church and others that the U.S. government had exceeded its mandates to collect intelligence against foreign threats in the name of enhanced state security. Fast forward forty years, where the NSA today does have the ability (as former NSA Director, General Keith Alexander noted) to "collect it all" and sort out later which information is necessary to prevent terrorist attacks.

In No Place to Hide, Greenwald begins with his personal account of meetings with Edward Snowden in Hong Kong in May 2013, where the extent of the NSA's domestic collection programs was made known. Greenwald recounts his own doubts initially about Snowden's credibility and motivation, as well as the risk to his own safety by meeting with Snowden. That quickly dissipates as Greenwald is presented with a treasure trove of highly classified, extremely sensitive documents, which he does publish in the text with their security classifications. Greenwald 
states that he struggled with the decision to make this information public, knowing the possible implications for releasing the actual documents. Yet, he argues in the text that the public's right to know the extent to which the U.S. government has violated U.S. citizen's civil liberties by conducting what he considered to be illegal actions clearly superseded the need to protect national security or intelligence sources and methods. Greenwald views Edward Snowden as a patriot, not a traitor, and he makes a case throughout the text to convince the reader that Snowden's actions were "heroic," placing himself at great risk of his own life and liberty to make the NSA's domestic collection programs known to the public. Greenwald argues that Snowden had no hidden agenda and that his actions were not part of some premeditated plan to "out" the intelligence agencies, or even gain financially for his actions. Yet, Greenwald himself has no qualms about benefitting personally from publishing the book and revealing classified information. He has been on a number of television programs, conducted interviews, and has taken it upon himself to speak on behalf of Snowden, who at this time remains in exile somewhere in Russia.

Although this is not a scholarly piece of literature, (e.g. none of the sources he quotes are documented or cited in the text - you have to go to his personal website to find them, and even then they are not complete) Greenwald does offer a thesis, or argument in his text. The first is that democratic governments must be held accountable for their actions and that the threat of terrorism does not give the president the authority to usurp the Constitution under the guise of national security. The second is that the "main stream media" is just as complicit in failing to confront political leaders by publishing controversial stories (such as his), and that many journalists are "captured" by the special interests they work for in the media. He does give credit to his former paper, The Guardian, in the United Kingdom for taking the risk of publishing his stories about Snowden and releasing classified information about the NSA collection programs.

It would be easy to dismiss Greenwald's book as little more than a myopic treatment of the government and the media based on his own biases. or be viewed by Republicans as one more example of "Bush bashing" by a liberal journalist. Yet, Greenwald's treatment of the Obama administration is just as harsh, if not more so, for allowing these intelligence programs to not 
only continue, but to expand during the last eight years with even less transparency and accountability by Democratic leaders. To that extent, Greenwald's book is an equal opportunity offender.

For intelligence professionals who worked with highly classified, sensitive materials, like those documents revealed by Edward Snowden (and published in the text), there is little to like about this book. Most would view Snowden as a traitor, who violated his oath to not disclose classified information, deserving to be tried and hopefully convicted. His fleeing to China and now Russia, two adversarial states regarding intelligence operations, did not help his cause. Many of those professionals would probably like to see Greenwald join him for his part in publishing the documents, much like Julian Assange's role at WikiLeaks in publishing classified documents provided by former Army Intelligence Specialist, Bradley (now Chelsea) Manning in 2010.

Yet, the issues raised by Snowden, Greenwald, Laura Poitras, Barton Gellman, and others who published information about the NSA's domestic collection programs are those that need to be addressed within the professional intelligence community, by policy makers, and academics. To what extent have these programs made Americans safer from terrorist attacks? At times of heightened threats, does security trump liberty? Does the end justify the means? Too often in my classrooms, I have heard students say flippantly, "well, if you have nothing to hide, then there is nothing to worry about." That is too simplistic a response when dealing with the nature of terror and technology today. The intelligence community, like all branches of government, needs to be held accountable by the public they serve. Journalists do have a right to exercise their role as the " $4^{\text {th }}$ estate" to check government power. Yet, they also have a responsibility to use their access to sensitive information in a way that does not compromise the ability of those institutions to protect sources and methods, which can put people's lives at risk.

No Place to Hide is as much about Glenn Greenwald as it is about Edward Snowden, the NSA, or excessive governmental power. If you can get beyond the self-adulation and ego of the author and move beyond the indignation of seeing highly classified information published (which has not been reviewed and declassified), there is story here that needs to be read and a topic that needs to be discussed and debated. 
Richard J. Kilroy, Jr., Ph.D., is Assistant Professor of Politics, Coastal Carolina University, Conway, SC. He is also a retired Army Intelligence Officer. 